\title{
Abietane diterpenoids from Sideritis montana L. and their antiproliferative activity
}

\author{
Barbara Tóth $^{\mathrm{a}}$, Norbert Kúsz ${ }^{\mathrm{a}}$, Peter Forgo ${ }^{\mathrm{a}}$, Noémi Bózsity ${ }^{\mathrm{b}}$, István Zupkób,d, Gyula Pinke ${ }^{\mathrm{c}}$, \\ Judit Hohmann ${ }^{\mathrm{a}, \mathrm{d}}$, Andrea Vasas ${ }^{\mathrm{a}, *}$ \\ a Department of Pharmacognosy, University of Szeged, 6720 Szeged, Hungary \\ b Department of Pharmacodynamics and Biopharmacy, University of Szeged, 6720 Szeged, Hungary \\ c Department of Botany, University of West Hungary, 9200 Mosonmagyaróvár, Hungary \\ d Interdisciplinary Centre of Natural Products, University of Szeged, 6720 Szeged, Hungary
}

\section{A R T I C L E I N F O}

\section{Keywords:}

Sideritis montana

Lamiaceae

Diterpenoids

Flavonoid

Antiproliferative activity

\begin{abstract}
A B S T R A C T
The present study aimed at the phytochemical and pharmacological investigation of Sideritis montana L. (Lamiaceae). Two new abietane diterpenes [sideritins A (1) and B (2)] were isolated from the methanol extract of the plant. Six known compounds [pomiferin E (3), 9 $\alpha, 13 \alpha$-epi-dioxyabiet-8(14)-en-18-ol (4), paulownin (5), 6-methoxysakuranetin (6), 3-oxo- $\alpha$-ionol (7) and 4-allyl-2,6-dimethoxyphenol glucoside (8)] were also obtained from the plant. The structures were determined by means of HREIMS and NMR experiments. The antiproliferative effect of the isolated compounds was investigated on human cancer cell lines (HeLa, SiHa and $\mathrm{C} 33 \mathrm{~A})$ at 10 and $30 \mu \mathrm{M}$ concentrations, using the MTT assay. The results demonstrated that pomiferin E (3) and 6-methoxysakuranetin (6) displayed considerable activity [inhibition (\%) \pm SEM: $46.93 \pm 2.35$ on HeLa (pomiferin E), and $51.52 \pm 2.45$ on C33A (6-methoxysakuranetin)] at $30 \mu \mathrm{M}$ concentration.
\end{abstract}

\section{Introduction}

The genus Sideritis (Lamiaceae family) includes more than 150 species, which are distributed widely in the Mediterranean area [1]. These plants are traditionally used as remedies for several disorders, such as anti-ulcerative, vulnerary, anticonvulsant, and analgesic agents. Infusions and decoctions prepared from Sideritis species are consumed frequently, since the extracts of plants possess different pharmacological activities, including antioxidant, anti-inflammatory, antimicrobial, spasmolytic and carminative effects [2].

Previously iridoid glycosides (ajugol, ajugoside and melittoside), a flavonoid (diosmetin), and a phenylethanoid glycoside (verbascoside) have been isolated from Sideritis montana $\mathrm{L}$. The volatile oil of the plant contains considerable amounts of sesquiterpenes, such as germacrene D and bicyclogermacrene. The triterpenoid constituents (ergosterol, stigmasterol and $\beta$-sitosterol) of $S$. montana seeds have also been identified by HPLC. Up to now, only one diterpenoid, siderol was described from the plant, but its detailed spectroscopic analysis was not reported [3]. The investigation of secondary metabolites of $S$. montana subsp. montana resulted in the identification of flavonoids (isoscutellarein derivatives), chlorogenic acid, methylarbutin and iridoids (e.g. harpagide, melittoside). The essential oil of the plant was mainly characterized by sesquiterpene hydrocarbons (germacrene D and bicyclogermacrene) [4].

Recently, the effect of hydroalcoholic extracts prepared from $S$. euboea and $S$. scardica (named as Greek mountain tea) was tested in Alzheimer's $\beta$-amyloidosis mouse models and investigated their activities on memory and learning processes. It was observed that daily oral treatment of the extracts enhanced cognition in aged, non-transgenic as well as in APP-transgenic mice. These results support the traditional use of Sideritis species in the prevention of age-related problems (e.g. dementing disorders like Alzheimer's disease) in elderly individuals [5]. The essential oil of $S$. montana subsp. montana showed moderate cytotoxicity on A375, MDA-MB 231 and HCT116 cell lines, and weak antioxidant activity [4].

The aim of the present study was to perform a preparative phytochemical work with $S$. montana, and to investigate the antiproliferative properties of the isolated compounds.

\section{Experimental}

\subsection{General}

Vacuum liquid chromatography (VLC) was carried out on silica gel

\footnotetext{
* Corresponding author.

E-mail address: vasasa@pharmacognosy.hu (A. Vasas).
} 
(15 $\mu \mathrm{m}$, Merck); LiChroprep RP-18 (40-63 $\mu \mathrm{m}$, Merck) stationary phase was used for reversed-phase VLC; column chromatography (CC) was performed on polyamide (MP Biomedicals). Preparative thin-layer chromatography (preparative TLC) was performed on silica gel $60 \mathrm{~F}_{254}$ plates (Merck) as well on reversed-phase silica gel $60 \mathrm{RP}-18 \mathrm{~F}_{254}$ plates (Merck). Rotation planar chromatography (RPC) was carried out on silica gel $60 \mathrm{GF}_{254}$ with a Chromatotron instrument (Model 8924, Harrison Research). Centrifugal partition chromatography (CPC) was performed on Armen SCPC apparatus (Armen Instrument Sas, SaintAvé, France) equipped with a gradient pump, a $10 \mathrm{~mL}$ sample loop, an ASC/DSC valve, a $250 \mathrm{~mL}$ column, a UV detector, and an automatic fraction collector. The system was controlled by Armen Glider software.

NMR spectra were recorded in $\mathrm{CDCl}_{3}$ and DMSO- $d_{6}$ on a Bruker Avance DRX 500 spectrometer at $500 \mathrm{MHz}\left({ }^{1} \mathrm{H}\right)$ and $125 \mathrm{MHz}\left({ }^{13} \mathrm{C}\right)$. The signals of the deuterated solvents were taken as references. The chemical shift values $(\delta)$ were given in ppm and coupling constants $(J)$ are in Hz. Two-dimensional (2D) experiments were performed with standard Bruker software. In the COSY, HSQC and HMBC experiments, gradient-enhanced versions were used. The high resolution MS spectra were acquired on a Thermo Scientific Q-Exactive Plus Orbitrap mass spectrometer equipped with ESI ion source in positive ionization mode. The resolution was over $1 \mathrm{ppm}$. The data were acquired and processed with MassLynx software. All solvents used for CC were of at least analytical grade (VWR Ltd., Szeged, Hungary).

\subsection{Plant material}

Sideritis montana was collected during the flowering period in July 2013, near Öskü (Hungary). Botanical identification of the plant material was performed by one of the authors, Dr. Gyula Pinke (Department of Botany, University of West Hungary, Mosonmagyaróvár, Hungary) and a voucher specimen (No 822) has been deposited at the Herbarium of the Department of Pharmacognosy, University of Szeged, Szeged, Hungary.

\subsection{Extraction and isolation}

The air-dried whole plant of $S$. montana $(2.8 \mathrm{~kg})$ was percolated with $\mathrm{MeOH}(60 \mathrm{~L})$ at room temperature. The crude methanol extract was concentrated under reduced pressure $(637.4 \mathrm{~g})$ and subjected to solvent-solvent partitioning with $n$-hexane, $\mathrm{CHCl}_{3}$, and EtOAc. $5 \times 1.5 \mathrm{~L}$ solvent was used for each partitioning.

The concentrated $n$-hexane soluble fraction (S1) ( $49.5 \mathrm{~g}$ ) was separated by polyamide open column chromatography with gradient system of $\mathrm{MeOH}-\mathrm{H}_{2} \mathrm{O}$ [2:3, 3:2, 4:1, 1:0 (3, 2.5, 3.5 and $2 \mathrm{~L}$, respectively), each eluent was collected as a fraction]. The fraction obtained from the polyamide column with $\mathrm{MeOH}-\mathrm{H}_{2} \mathrm{O} 3: 2(\mathrm{~S} 1 / 2)(2.43 \mathrm{~g})$ was subjected to vacuum liquid chromatography on silica gel (VLC, Kieselgel $\mathrm{GF}_{254}$, Merck) with a gradient system of cyclohexane-EtOAc-MeOH [from 9:1:0 to 5:5:1 (200 mL/eluent), and finally with $\mathrm{MeOH}(150 \mathrm{~mL})$; volume of collected fractions were $20 \mathrm{~mL}$ ] to yield the major fractions $\mathrm{S} 1 / 2 / 1-6$. The fractions were combined according to their TLC patterns, using cyclohexane-EtOAc-MeOH (20:10:1) as solvent system (detection at 254 and $366 \mathrm{~nm}$, and at daylight after spraying with vanillin-sulfuric acid reagent and heating at $120{ }^{\circ} \mathrm{C}$ for $5 \mathrm{~min}$ ).

Fraction S1/2/2 (48.7 mg) was separated by reversed-phase VLC, which was eluted with a gradient system of $\mathrm{MeOH}-\mathrm{H}_{2} \mathrm{O}$ [from 2:3 to 9:1 (100 mL/eluent), and finally $\mathrm{MeOH}(100 \mathrm{~mL})$; volume of collected fractions was $10 \mathrm{~mL}$ ] to yield six subfractions. Compound 3 (4.2 mg) was obtained from subfraction $\mathrm{S} 1 / 2 / 2 / 5(13.6 \mathrm{mg})$ by preparative TLC on silica gel $60 \mathrm{~F}_{254}$ plates using toluene-acetone (8:2) as solvent system.

Fraction $\mathrm{S} 1 / 2 / 3$ (38.0 mg) was also purified by reversed-phase VLC, a gradient system of $\mathrm{MeOH}-\mathrm{H}_{2} \mathrm{O}$ [from 3:7 to 9:1 (100 mL/eluent), and finally $\mathrm{MeOH}(100 \mathrm{~mL})$ ] was used as eluent; (volume of collected fractions was $10 \mathrm{~mL}$ ) to afford five subfractions. From subfraction $\mathrm{S} 1 /$ 2/3/3 (14.3 $\mathrm{mg}$ ) compound 5 ( $4.7 \mathrm{mg}$ ) was purified by preparative TLC on silica gel $60 \mathrm{~F}_{254}$ plates using toluene-acetone (8:2) as solvent system.

Reversed-phase VLC was used for the separation of fraction $\mathrm{S} 1 / 2 / 4$ (117.1 mg). The fraction was eluted by a gradient system of $\mathrm{MeOH}-\mathrm{H}_{2} \mathrm{O}$ [from 3:7 to 9:1 (120 mL/eluent), and finally $\mathrm{MeOH}(150 \mathrm{~mL})$, volume of collected fractions was $10 \mathrm{~mL}$ ] to afford nine subfractions. By the use of preparative TLC on silica gel $60 \mathrm{~F}_{254}$ plates using toluene-acetone (8:2) as solvent system compound $1(5.7 \mathrm{mg})$ and compound $4(3.1 \mathrm{mg})$ were isolated from subfractions $\mathrm{S} 1 / 2 / 4 / 3(11.1 \mathrm{mg})$ and $51 / 2 / 4 / 6$ ( $9.3 \mathrm{mg})$, respectively.

Fraction S1/2/5 (148.3 mg) was also chromatographed by reversedphase VLC, which was eluted with a gradient system of $\mathrm{MeOH}-\mathrm{H}_{2} \mathrm{O}$ [from 3:7 to 9:1 (150 mL/eluent), and finally $\mathrm{MeOH}(100 \mathrm{~mL})$; volume of collected fractions was $10 \mathrm{~mL}$ ] to afford five combined fractions. Fraction $S 1 / 2 / 5 / 1(24.1 \mathrm{mg})$ was purified by the use of preparative TLC on silica gel $60 \mathrm{~F}_{254}$ plates using toluene-acetone (8:2) as solvent system to yield compound $2(7.2 \mathrm{mg})$ and compound $6(4.6 \mathrm{mg})$.

The $\mathrm{CHCl}_{3}$-soluble fraction (S2) (35.5 g) was chromatographed on a polyamide column with gradient system of $\mathrm{MeOH}-\mathrm{H}_{2} \mathrm{O}[1: 4,2: 3,3: 2$, $4: 1,1: 0(2.5,2.5,3,3.5$, and $2 \mathrm{~L}$, respectively)] to give nine combined fractions (S2/1-9). Fraction S2/1 (5.73 g) was further chromatographed by VLC on silica gel with a gradient system of $\mathrm{CHCl}_{3}-\mathrm{MeOH}$ [from 100:1 to 1:1 (500 mL/eluent), and finally with $\mathrm{MeOH}(400 \mathrm{~mL})$; volume of collected fractions were $50 \mathrm{~mL}$ ] to yield twelve major fractions (S2/ 1/1-12). The fractions were concentrated and monitored by TLC using $\mathrm{CHCl}_{3}-\mathrm{MeOH}$ (95:5 and 9:1) and EtOAc-EtOH- $\mathrm{H}_{2} \mathrm{O}$ (25:4:3) as solvent system. Subfraction $\mathrm{S} 2 / 1 / 4(225.4 \mathrm{mg})$ was separated by RPC on silica gel $60 \mathrm{GF}_{254}$ with the use of $\mathrm{CH}_{2} \mathrm{Cl}_{2}-\mathrm{MeOH}$ gradient elution [from 99:1 to $7: 3(150 \mathrm{~mL} /$ eluent), and finally with $\mathrm{MeOH}(100 \mathrm{~mL})$; volume of collected fractions were $20 \mathrm{~mL}$ ] to yield seven subfractions. Compound 7 (3.9 mg) was purified from subfraction $\mathrm{S} 2 / 1 / 4 / 4$ (30.2 mg) using preparative TLC on reversed-phase silica gel $60 \mathrm{RP}-18 \mathrm{~F}_{254}$ plates with $\mathrm{MeOH}-\mathrm{H}_{2} \mathrm{O}(7: 3)$ as solvent system.

Fraction S2/1/9 (960.3 mg) was chromatographed with CPC, using a two-phase solvent system consisting of $\mathrm{CHCl}_{3}-\mathrm{MeOH}-\mathrm{H}_{2} \mathrm{O}$ 10:3:7 (1000 rpm, $10 \mathrm{~mL} / \mathrm{min}$ flow rate, $90 \mathrm{~min}$ ) in the ascending mode. After combination eight subfractions were obtained. From subfraction S2/1/ 9/4 (24.5 mg) compound 8 (4.7 $\mathrm{mg}$ ) was isolated by the use of preparative TLC on reversed-phase silica gel $60 \mathrm{RP}-18 \mathrm{~F}_{254}$ plates with $\mathrm{MeOH}-\mathrm{H}_{2} \mathrm{O}(7: 3)$ as eluent.

\subsubsection{Sideritin A (1)}

Yellow amorphous solid; $[\alpha]_{\mathrm{D}}{ }^{26}+47(c 0.1, \mathrm{MeOH}) ;{ }^{1} \mathrm{H}$ and ${ }^{13} \mathrm{C}$ NMR data see Table 1; HRESIMS $m / z 285.2217\left[\mathrm{M}-\mathrm{H}_{2} \mathrm{O}+\mathrm{H}\right]^{+}$(calcd for $\mathrm{C}_{20} \mathrm{H}_{29} \mathrm{O}, 285.2213$ ).

\subsubsection{Sideritin $B(2)$}

Yellow amorphous solid; $[\alpha]_{\mathrm{D}}{ }^{26}-7(c \quad 0.2, \mathrm{MeOH}) ;{ }^{1} \mathrm{H}$ and ${ }^{13} \mathrm{C}$ NMR data see Table 1; HRESIMS $m / z 359.2198[\mathrm{M}+\mathrm{Na}]^{+}$(calcd for $\mathrm{C}_{20} \mathrm{H}_{32} \mathrm{O}_{4} \mathrm{Na}$, 359.2193) providing the molecular formula, $\mathrm{C}_{20} \mathrm{H}_{32} \mathrm{O}_{4}$.

\subsubsection{Pomiferin E (3)}

${ }^{13} \mathrm{C}$ NMR $\left(\mathrm{CDCl}_{3}, 125 \mathrm{MHz}\right) \delta 199.3(\mathrm{C}=\mathrm{O}, \mathrm{C}-7), 152.7$ (C, C-9), 147.1 (C, C-13), 132.7 (CH, C-12), 130.5 (C, C-8), 125.1 (CH, C-14), 123.4 (CH, C-11), 65.0 (CH, C-2), $50.5\left(\mathrm{CH}_{2}, \mathrm{C}-3\right), 48.7$ (C, C-4), 46.9 $\left(\mathrm{CH}_{2}, \mathrm{C}-1\right), 39.4(\mathrm{C}, \mathrm{C}-10), 36.0\left(\mathrm{CH}_{2}, \mathrm{C}-6\right), 34.8(\mathrm{CH}, \mathrm{C}-15), 33.6\left(\mathrm{CH}_{3}\right.$, C-19), $32.6(\mathrm{CH}, \mathrm{C}-5), 23.8\left(\mathrm{CH}_{3}, \mathrm{C}-16\right), 23.7\left(\mathrm{CH}_{3}, \mathrm{C}-17\right), 24.4\left(\mathrm{CH}_{3}, \mathrm{C}-\right.$ 20), $22.0\left(\mathrm{CH}_{3}, \mathrm{C}-18\right)$.

\subsection{Bioassay}

Antiproliferative effect of the isolated compounds (1-7) were measured in vitro on human cervical cancer cell lines (HeLa, SiHa, and C33A) using the 3-(4,5-dimethylthiazol-2-yl)-2,5-diphenyltetrazolium 
Table 1

NMR data for sideritin A (1).

\begin{tabular}{|c|c|c|c|c|}
\hline \multirow[t]{2}{*}{ position } & \multicolumn{2}{|l|}{$1^{\mathrm{a}}$} & \multicolumn{2}{|l|}{$2^{\mathrm{b}}$} \\
\hline & $\delta_{\mathrm{H}}(J$ in $\mathrm{Hz})$ & $\delta_{\mathrm{C}}$, type & $\delta_{\mathrm{H}}(J$ in $\mathrm{Hz})$ & $\delta_{\mathrm{C}}$, type \\
\hline $1 \alpha$ & $1.04, \mathrm{t}(11.8)$ & 47.8, $\mathrm{CH}_{2}$ & $1.70, \mathrm{~m}$ & 41.6, $\mathrm{CH}_{2}$ \\
\hline $1 \beta$ & 2.45, brd (11.7) & & $1.79, \mathrm{~m}$ & \\
\hline 2 & $3.81, \mathrm{~m}$ & $63.0, \mathrm{CH}$ & $3.85, \mathrm{~m}$ & $65.1, \mathrm{CH}$ \\
\hline $3 \alpha$ & $1.04, \mathrm{t}(10.6)$ & $50.5, \mathrm{CH}_{2}$ & $1.14, \mathrm{~m}$ & $51.3, \mathrm{CH}_{2}$ \\
\hline $3 \beta$ & 1.69, brd (10.6) & & $1.75, \mathrm{~m}$ & \\
\hline 4 & & $34.0, \mathrm{C}$ & & $35.2, \mathrm{C}$ \\
\hline 5 & 1.20, brd (12.7) & $48.4, \mathrm{CH}$ & $1.56, \mathrm{~m}$ & 42.6, CH \\
\hline $6 \alpha$ & 2.01, dd $(12.3,7.1)$ & 29.3, $\mathrm{CH}_{2}$ & $2.26, \mathrm{~m}$ & 29.0, $\mathrm{CH}_{2}$ \\
\hline $6 \beta$ & $1.55, \mathrm{~m}$ & & $1.56, \mathrm{~m}$ & \\
\hline 7 & 4.53, dd $(10.0,7.1)$ & $69.4, \mathrm{CH}$ & 4.71, dd $(10.1,2.8)$ & $67.3, \mathrm{CH}$ \\
\hline 8 & & 138.9, C & & 146.6, C \\
\hline 9 & & 146.3, C & & $81.2, \mathrm{C}$ \\
\hline 10 & & $39.3, \mathrm{C}$ & & $41.0, \mathrm{C}$ \\
\hline $11(\alpha)$ & $7.12, \mathrm{~d}(8.2)$ & 123.6, CH & $2.12, \mathrm{~m}$ & 23.4, $\mathrm{CH}_{2}$ \\
\hline $11 \beta$ & & & $1.55, \mathrm{~m}$ & \\
\hline 12 & $7.03, \mathrm{~d}(7.7)$ & $124.8, \mathrm{CH}$ & $1.99,2 \mathrm{H}, \mathrm{m}$ & 24.9, $\mathrm{CH}_{2}$ \\
\hline 13 & & $145.0, \mathrm{C}$ & & $79.8, \mathrm{C}$ \\
\hline 14 & 7.33 , brs & 125.3, CH & $6.47, \mathrm{~s}$ & 133.7, $\mathrm{CH}$ \\
\hline 15 & 2.81 , sept (6.9) & $33.1, \mathrm{CH}$ & $1.94, \mathrm{~m}$ & $32.4, \mathrm{CH}$ \\
\hline 16 & $1.17,3 \mathrm{H}, \mathrm{d}(7.2)$ & $23.9, \mathrm{CH}_{3}$ & $1.01,3 \mathrm{H}, \mathrm{d}(8.0)$ & $17.4, \mathrm{CH}_{3}$ \\
\hline 17 & $1.16,3 \mathrm{H}, \mathrm{d}(7.2)$ & $24.0, \mathrm{CH}_{3}$ & $0.99,3 \mathrm{H}, \mathrm{d}(8.0)$ & $17.5, \mathrm{CH}_{3}$ \\
\hline 18 & $0.90,3 \mathrm{H}, \mathrm{s}$ & $22.4, \mathrm{CH}_{3}$ & $0.99,3 \mathrm{H}, \mathrm{s}$ & $24.0, \mathrm{CH}_{3}$ \\
\hline 19 & $0.94,3 \mathrm{H}, \mathrm{s}$ & $33.2, \mathrm{CH}_{3}$ & $0.95,3 \mathrm{H}, \mathrm{s}$ & $33.1, \mathrm{CH}_{3}$ \\
\hline 20 & $1.16,3 \mathrm{H}, \mathrm{s}$ & $26.1, \mathrm{CH}_{3}$ & $1.26,3 \mathrm{H}, \mathrm{s}$ & $20.0, \mathrm{CH}_{3}$ \\
\hline $2-\mathrm{OH}$ & $4.45, \mathrm{~d}(4.8)$ & & & \\
\hline 7-OH & $5.19, \mathrm{~d}(7.3)$ & & & \\
\hline
\end{tabular}

${ }^{\text {a }}$ Recorded in DMSO- $d_{6}$ at $500 \mathrm{MHz}\left({ }^{1} \mathrm{H}\right)$ and $125 \mathrm{MHz}\left({ }^{13} \mathrm{C}\right)$.

${ }^{b}$ Recorded in $\mathrm{CDCl}_{3}$ at $500 \mathrm{MHz}\left({ }^{1} \mathrm{H}\right)$ and $125 \mathrm{MHz}\left({ }^{13} \mathrm{C}\right)$.

bromide (MTT) colorimetric assay. These cell lines were purchased from the European Collection of Cell Cultures (Salisbury, UK) and maintained in minimal essential medium supplemented with $10 \%$ fetal bovine serum, $1 \%$ nonessential amino acids, and an antibiotic-antimycotic mixture, in a humidified atmosphere of $5 \% \mathrm{CO}_{2}$ at $37^{\circ} \mathrm{C}$. All of the chemicals, if otherwise not specified, were purchased from SigmaAldrich Ltd. (Budapest, Hungary). The cytotoxicity tests were carried out in 96-well microtitre plates, using 5000 cells/well for HeLa and $\mathrm{SiHa}$ and 10,000 cells/well for C33A cells, which were allowed to adhere overnight before the drugs were introduced. The original medium was then removed, $200 \mu \mathrm{L}$ culture medium containing the compounds of interest was added and the cells were incubated for $72 \mathrm{~h}$. The tested extracts and compounds were dissolved in DMSO. The final concentration of DMSO never exceeded $0.3 \%$, and therefore had no essential effect on the cell growth. Next, the living cells were assayed: aliquots $(20 \mu \mathrm{L}$ at $5 \mathrm{mg} / \mathrm{mL})$ of the MTT stock solution were pipetted into each well and reduced by viable cells to an insoluble formazan product during a further $4 \mathrm{~h}$. The precipitated formazan crystals were solubilized in $100 \mu \mathrm{L}$ DMSO by gentle shaking for $60 \mathrm{~min}$. The absorbance was determined at $545 \mathrm{~nm}$ with an enzyme-linked immunosorbent assay reader [6]. In this way the cell growth or drug toxicity was determined. All in vitro experiments were carried out on two microplates with five parallel wells. Based on our previous antiproliferative activity experiments, cisplatin ( $\mathrm{IC}_{50} 12.43 \mu \mathrm{M}$, $7.84 \mu \mathrm{M}$, and $3.69 \mu \mathrm{M}$, on HeLa, SiHa, and C33A cells, respectively), a clinically used anticancer agent, was used as the reference substance [7].

\section{Results and discussion}

In the course of our study, the phytochemical and pharmacological investigations of Sideritis montana L. were performed. The dried whole plant material $(2.8 \mathrm{~kg}$ ) was powdered and extracted with $\mathrm{MeOH}$ at room temperature. After concentration, the extract was dissolved in $50 \%$ aqueous $\mathrm{MeOH}$, and solvent-solvent partition was performed with $n$-hexane, $\mathrm{CHCl}_{3}$, and finally with EtOAc. The $n$-hexane, and $\mathrm{CHCl}_{3}$ fractions were purified with a combination of different chromatographic techniques to yield eight compounds (1-8) (Fig. 1). The structure elucidation of the compounds was carried out by extensive spectroscopic analysis, using 1D and 2D NMR $\left({ }^{1} \mathrm{H}-{ }^{1} \mathrm{H}\right.$ COSY, HSQC, HMBC, NOESY) spectroscopy, HRESIMS experiments and comparison of the spectral data with literature values.

Compound 1 was obtained as an amorphous solid with $[\alpha]_{\mathrm{D}}{ }^{26}+47$ (c 0.1, MeOH). Its HRESIMS proved the molecular formula $\mathrm{C}_{20} \mathrm{H}_{30} \mathrm{O}_{2}$ through the presence of a peak at $m / z 285.2217\left[\mathrm{M}-\mathrm{H}_{2} \mathrm{O}+\mathrm{H}\right]^{+}$(calcd for $\mathrm{C}_{20} \mathrm{H}_{29} \mathrm{O}, 285.2213$ ) and supported by the hydrogen and carbon atom counts in the NMR spectra. The ${ }^{1} \mathrm{H}$ NMR spectrum (Table 1) displayed signals of two ortho-coupled aromatic protons $\left(\delta_{\mathrm{H}} 7.12 \mathrm{~d}\right.$ and $7.03 \mathrm{~d})$, and one aromatic proton as a broad singlet $\left(\delta_{\mathrm{H}} 7.33\right)$, five methyls, three methylenes, four $s p^{3}$ methines and signals of protons belonging to two hydroxyl groups. In the JMOD ( $J$-modulated spin-echo experiment) spectrum, the presence of 20 carbon signals was detected (Table 1) indicating this compound to be a diterpene. In the ${ }^{1} \mathrm{H}-{ }^{1} \mathrm{H}$ COSY spectrum, correlations were observed between protons at $\delta_{\mathrm{H}}$ $3.81 \mathrm{~m}$ and $1.04 \mathrm{t}$ and $2.45 \mathrm{brd}(\mathrm{H}-2 / \mathrm{H}-1 \alpha, \mathrm{H}-1 \beta$ and $\mathrm{H}-3 \alpha), \delta_{\mathrm{H}} 1.55 \mathrm{~m}$ and 1.20 brd and $4.53 \mathrm{dd}(\mathrm{H}-6 \beta / \mathrm{H}-5$ and $\mathrm{H}-7), \delta_{\mathrm{H}} 2.01 \mathrm{dd}$ and $4.53 \mathrm{dd}$ $(\mathrm{H}-6 \alpha / \mathrm{H}-7), \delta_{\mathrm{H}} 7.12 \mathrm{~d}$ and $7.03 \mathrm{brd}(\mathrm{H}-11 / \mathrm{H}-12)$, and $\delta_{\mathrm{H}} 2.81$ sept and $1.16 \mathrm{~d}(3 \mathrm{H})$ and $1.17 \mathrm{~d}(3 \mathrm{H})\left(\mathrm{H}-15 / \mathrm{H}_{3}-16\right.$ and $\left.\mathrm{H}_{3}-17\right)$ (Fig. 2).

These structural parts and quaternary carbons were connected by inspection of the long-range $\mathrm{H}-\mathrm{C}$ correlations observed in the HMBC spectrum (Fig. 2). The two- and three-bond correlations between $\mathrm{H}-1$, $\mathrm{H}-5, \mathrm{H}-6, \mathrm{H}-11$ and $\mathrm{H}_{3}-20$ and the quaternary carbon C-10; $\mathrm{H}-1, \mathrm{H}-5, \mathrm{H}-$ $12, \mathrm{H}-14$, and $\mathrm{H}-20$ and the quaternary carbon C-9; H-6, H-7, H-11 and $\mathrm{C}-8$; and finally $\mathrm{H}-11, \mathrm{H}-14, \mathrm{H}-15$ and $\mathrm{C}-13$ revealed that the structure forms an abietane skeleton, frequently occur in different Lamiaceae species. Two of the methyl groups $\left(\delta_{\mathrm{H}} 0.94 \mathrm{~s}\right.$ and $\left.0.90 \mathrm{~s}\right)$ were placed at $\mathrm{C}-4$ on the basis of their HMBC correlations with the quaternary carbon at $\delta_{\mathrm{C}} 34.0(\mathrm{C}-4)$, and $\delta_{\mathrm{C}} 50.5(\mathrm{C}-3)$ and $\delta_{\mathrm{C}} 48.4$ (C-5). Another methyl group was connected to $\mathrm{C}-10$ according to its long-range correlation $\mathrm{H}_{3}$ 20/C-10. The linkage of hydroxy groups to C-2 and C-7 were confirmed by the chemical shift of the tertiary carbons $\left(\delta_{\mathrm{C}-2} 63.0\right.$ and $\left.\delta_{\mathrm{C}-7} 69.4\right)$.

The NOESY correlations confirmed the stereostructure of compound 1. Overhauser effects were detected between $\mathrm{H}-1 \alpha / \mathrm{H}-3 \alpha, \mathrm{OH}-2 / \mathrm{H}-1 \alpha$, $\mathrm{H}-2 / \mathrm{H}_{3}-18$ and $\mathrm{H}-20, \mathrm{H}-6 \alpha / \mathrm{H}-19, \mathrm{OH}-7 / \mathrm{H}-6 \beta$, and $\mathrm{H}-7 / \mathrm{H}-5$ and $\mathrm{H}-6 \alpha$. All of the above evidence confirmed the structure of 1 , named as sideritin A.

Compound 2 was isolated as an amorphous powder with $[\alpha]_{\mathrm{D}}{ }^{26}-7$

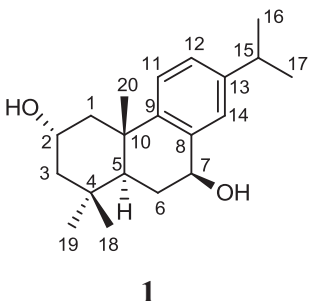

1

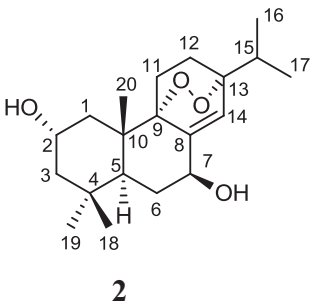

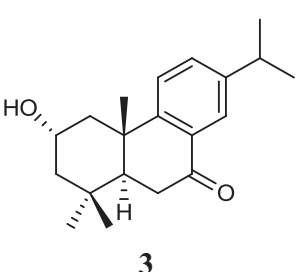<smiles>CC(C)C1C=C2CC[C@H]3[C@@H](C)CCC[C@]3(C)[C@]2(C)CC1</smiles>

Fig. 1. Structures of compounds 1-4. 


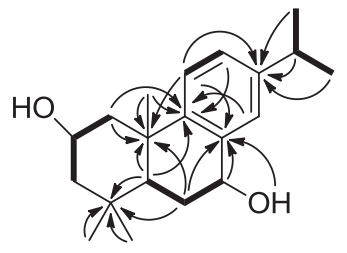

1

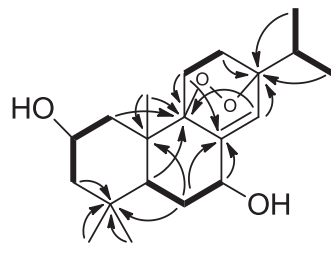

2
Fig. 2. Diagnostic COSY $(\square)$ and HMBC correlations $(\mathrm{H} \rightarrow \mathrm{C})$ for $\mathbf{1}$ and $\mathbf{2}$.

(c 0.2, $\mathrm{MeOH}$ ). Its HRESIMS provided the molecular formula, $\mathrm{C}_{20} \mathrm{H}_{32} \mathrm{O}_{4}$, through the presence of a peak at $\mathrm{m} / \mathrm{z} 359.2198\left[\mathrm{M}+\mathrm{Na}{ }^{+}\right.$(calcd for $\mathrm{C}_{20} \mathrm{H}_{32} \mathrm{O}_{4} \mathrm{Na}$, 359.2193). The ${ }^{1} \mathrm{H}$ NMR spectrum (Table 1 ) showed signals characteristic of three tertiary methyls $\left(\delta_{\mathrm{H}} 0.95 \mathrm{~s}, 0.99 \mathrm{~s}\right.$, and $1.26 \mathrm{~s})$, one isopropyl $\left(\delta_{\mathrm{H}} 1.94 \mathrm{~m}, 0.99 \mathrm{~d}\right.$ and $\left.1.01 \mathrm{~d}\right)$ and one olefinic proton signal ( $\delta_{\mathrm{H}} 6.47 \mathrm{~s}$ ). The JMOD spectrum (Table 1) confirmed the presence of a trisubstituted double bond ( $\delta_{\mathrm{C}} 133.7$ and 146.6), and also showed signals attributed to the presence of two quaternary oxygenated carbons $\left(\delta_{\mathrm{C}} 81.2\right.$ and 79.8). Thus, analysis of its ${ }^{1} \mathrm{H}$ and ${ }^{13} \mathrm{C}$ NMR data suggested that 2 is based on an epi-dioxyabietene structure [8].

According to the correlations observed in the ${ }^{1} \mathrm{H}-{ }^{1} \mathrm{H}$ COSY spectrum the same structural parts could be deduced as in case of $\mathbf{1}$ with exception of the aromatic ortho protons which are replaced by the two correlated methylenes $\left[\delta_{\mathrm{H}} 1.99 \mathrm{~m}(2 \mathrm{H}), 2.12 \mathrm{~m}(1 \mathrm{H})\right.$ and $\left.1.55 \mathrm{~m}(1 \mathrm{H})\right]$. The long-range $\mathrm{H}-\mathrm{C}$ correlations observed in the $\mathrm{HMBC}$ spectrum (Fig. 2) between $\mathrm{H}-14$ and C-7, C-9, C-12, C-13, and C-15 proved that an oxygen functionality was present between the C-9 and C-13, which was identified as an endoperoxide with regard to the molecular formula. According to their HMBC correlations methyl groups were placed at C-4 and C-10, and hydroxyl groups at C-2 and C-7, similarly as in case of $\mathbf{1}$.

The NOESY correlations further confirmed the structure of compound 2. Overhauser effects were detected between $\mathrm{H}-5 / \mathrm{H}-6 \alpha, \mathrm{H}-7$ and $\mathrm{H}_{3}-19, \mathrm{H}_{3}-19 / \mathrm{H}-6 \alpha$, and between $\mathrm{H}_{3}-20 / \mathrm{H}-1 \beta, \mathrm{H}-2, \mathrm{H}-6 \beta$ and $\mathrm{H}-11 \beta$. The relative stereochemistry at the epoxide for C-9 and C-13 in 2 was established as $\alpha, \alpha$ by NOESY correlations between $\mathrm{H}_{3}-20$ and $\mathrm{H}-11 \beta$, similarly as it was observed in case of angustanoic acid B [9]. All these evidence confirmed the structure of 2 , named sideritin $B$.

Besides the two new diterpenes, sideritin A (1) and B (2), two known diterpenoids, pomiferin E (3) [10], 9 $\alpha, 13 \alpha$-epi-dioxyabiet8(14)-en-18-ol (4) [8], the lignan paulownin (5) [11], the flavanone 6methoxysakuranetin (6) [12], the megastigmane 3-oxo- $\alpha$-ionol (7) [13], and 4-allyl-2,6-dimethoxyphenol-glucoside (8) [14] were also isolated from the methanol extract of $S$. montana. All of the compounds were isolated for the first time from the plant, however 6-methoxysakuranetin (6) was previously reported from other Sideritis species $(S$. sventenii) [12]. Since the genus Sideritis is a rich source of flavonoids, the presence of 6-methoxysakuranetin (6) in the plant was expectedly [3]. Compounds 1-3 contain hydroxyl group at C-2, which is rare in nature; such type of components were isolated previously from Salvia pomifera and Cryptomeria fortune[10,15]. Although great deals of diterpenoids were isolated from Sideritis species, until now these compounds have not been detected or isolated from $S$. montana[16]. Four compounds were obtained earlier from other Lamiaceae species, 3-oxoalfa-ionol (7) and 4-allyl-2,6-dimethoxyphenol-glucoside (8) were isolated from Glechoma longituba[17,18], pomiferin E (3) was identified from S. pomifera[10] and compound 4 from Hyptis suaveolens [19]. The ${ }^{13} \mathrm{C}$ NMR data of $\mathbf{3}$ was published here for the first time (see Section 2.3.3).

Diterpenes can be considered as chemotaxonomic markers for plants belonging to the genus Sideritis. S. montana was categorized into the Hesiodia section. Plants belonging to this section produces triterpenes or sterols, but among their secondary metabolites diterpenoids were not found [20]. The isolation of diterpenoids with unusual 2-hydroxy substitution from $S$. montana confirms its close relationship with the section Empedoclea[3,20].
Previously, abietane-type diterpenes were tested for their antitumor-promoting activities, by measuring the inhibitory activity of the compounds on EBV-EA (Epstein-Barr virus early antigen) activation induced by TPA (12-O-tetradecanoylphorbol-13-acetate) and potent or moderate inhibitory effects were observed $[21,22]$. In our study, the antiproliferative properties of the isolated compounds were determined on three human cancer (HeLa, SiHa and C33A) cell lines, at 10 and $30 \mu \mathrm{M}$ concentrations. In the performed assay, in vitro cell growth inhibitory effects were measured by the use of MTT assay. Among the isolated compounds, considerable inhibitory activities (above $40 \%$ growth inhibition) were measured for pomiferin E (3) on HeLa cell line (inhibition (\%) \pm SEM: $46.93 \pm 2.35$ ) and for 6-methoxysakuranetin (6) on C33A cells (inhibition (\%) \pm SEM: $51.52 \pm 2.45$ ), at $30 \mu \mathrm{M}$ concentration. Moderate inhibitory effects (20-40\% growth inhibition) were detected for sideritin A (1) on HeLa $(28.34 \pm 2.46 \%)$ and SIHA cells $(26.87 \pm 0.88 \%)$, pomiferin $\mathrm{E}$ (3) on SIHA cells $(24.49 \pm 2.22 \%)$ and compound 6 on HeLa $(39.70 \pm 2.64 \%)$ and SIHA $(35.49 \pm 2.49 \%)$ cells, at $30 \mu \mathrm{M}$ concentration. Other compounds proved to be inactive on the tested cell lines.

Previously, 9 $\alpha, 13 \alpha$-epi-dioxyabiet-8(14)-en-18-ol (4) was tested against A549 (human lung carcinoma), H-116 (human colon carcinoma), PSN1 (human pancreatic adenocarcinoma), T98G (human caucasian gioblastoma), and SKBR3 (human breast carcinoma) cell lines, but it had no inhibitory effect on them [8]. In our study, this compound was also proved to be inactive on the tested cell lines. The antiproliferative property of the other isolated compounds was not studied before.

In conclusion, our results allowed the identification of four abietane diterpenes (1-4) substituted with hydroxyl and endoperoxide groups, two of them [sideritins A (1) and B (2)] are new natural products. Moreover, a lignan (5), a flavanone (6) a methoxystigmane (7), and a phenol-glucoside (8) were also isolated from the plant. Finally, this was the first time when the antiproliferative properties of the abovementioned compounds were established and remarkable activities were detected for pomiferin E (3) and 6-methoxysakuranetin (6).

\section{Acknowledgments}

Financial supports from the Hungarian Scientific Research Fund (OTKA K109846, GINOP-2.3.2-15-2016-00012) and TÁMOP 4.2.4.A/211/1-2012-0001 are gratefully acknowledged. A.V. was supported by the János Bolyai Research Scholarship of the Hungarian Academy of Sciences.

\section{Conflict of interest}

The authors declare no competing financial interest.

\section{References}

[1] The plant list, http://www.theplantlist.org/tpl1.1/search?q= sideritis + montana (accessed 16.04.17).

[2] E. González-Burgos, M.E. Carretero, M.P. Gómez-Serranillos, Sideritis spp.: uses, chemical composition and pharmacological activities - a review, J. Ethnopharmacol. 135 (2011) 209-225.

[3] B.M. Fraga, Phytochemistry and chemotaxonomy of Sideritis species from the Mediterranean region, Phytochemistry 76 (2012) 7-24.

[4] A. Vendetti, A. Bianco, C. Frezza, M. Serafini, G. Giacomello, C. Giuliani, M. Bramucci, L. Quassinti, G. Lupidi, D. Lucarini, F. Papa, F. Maggi, Secondary metabolites, glandular trichomes and biological activity of Sideritis montana L. subsp. montana from Central Italy, Chem. Biodivers. 13 (2016) 1380-1390.

[5] J. Hofrichter, M. Krohn, T. Schumacher, C. Lange, B. Feistel, B. Walbroel, J. Pahnke, Sideritis spp. extracts enhance memory and learning in Alzheimer's $\beta$-amyloidosis mouse models and aged C57B1/6 mice, J. Alzheimers Dis. 53 (2016) 967-980.

[6] T. Mosmann, Rapid colorimetric assay for cellular growth and survival: application to proliferation and cytotoxicity assays, J. Immunol. Methods 65 (1983) 55-63.

[7] G. Schneider, A. Kiss, E. Mernyák, Z. Benke, J. Wölfling, É. Frank, N. Bózsity, A. Gyovai, R. Minorics, I. Zupkó, Stereocontrolled synthesis of the four 16-hydroxymethyl-19-nortestosterone isomers and their antiproliferative activities, Steroids 105 (2016) 113-120. 
[8] A.F. Barrero, J.F. Quílez del Moral, M.M. Herrador, J.F. Arteaga, M. Akssira, A. Benharref, M. Dakir, Abietane diterpenes from the cones of Cedrus atlantica, Phytochemistry 66 (2005) 105-111.

[9] L.K. Sy, G.D. Brown, Abietane diterpenes from Illicium angustisepalum, J. Nat. Prod. 61 (1998) 907-912.

[10] A. Ulubelen, G. Topcu, Abietane diterpenoids from Salvia pomifera, Phytochemistry 31 (1992) 3949-3951.

[11] S.R. Angle, I. Choi, F.S. Tham, Stereoselective synthesis of 3-alkyl-2-aryltetrahydrofuran-4-ols: Total synthesis of ( \pm )-paulownin, J. Organomet. Chem. 73 (2008) 6268-6278.

[12] C. Fernandez, B.M. Fraga, M.G. Hernandez, Flavonoid aglycones from some Canary islands species of Sideritis, J. Nat. Prod. 51 (1988) 591-593.

[13] A. Pabst, D. Barron, E. Sémon, P. Schreier, Two diastereomeric 3-oxo- $\alpha$-ionol $\alpha$-Dglucosides from raspberry fruit, Phytochemistry 31 (1992) 1649-1652.

[14] T. Miyase, M. Kuroyanagi, T. Noro, A. Ueno, S. Fukushima, Studies on sesquiterpenes from Macroclinidium trilobum MAKINO. II, Chem. Pharm. Bull. 33 (1985) 4445-4450.

[15] S. Yao, C.P. Tang, C.Q. Ke, Y. Ye, Abietane diterpenoids from the bark of
Cryptomeria fortunei, J. Nat. Prod. 71 (2008) 1242-1246.

[16] F. Piozzi, M. Bruno, S. Rosselli, A. Maggio, The diterpenoids from the genus Sideritis, Stud. Nat. Prod. Chem. 33 (2006) 493-540.

[17] N.Y. Yang, J.A. Duan, P. Li, S.H. Qian, Chemical constituents of Glechoma longituba, Acta Pharm. Dermatol. Sin. 41 (2006) 431-434 (Abstract).

[18] Y.D. Zhu, J. Zou, W.M. Zhao, Two new monoterpenoid glycosides from Glechoma longituba, J. Asian Nat. Prod. Res. 10 (2008) 199-204.

[19] J.C. Chukwujekwu, P. Smith, P.H. Coombes, D.A. Mulholland, J. van Staden, Antiplasmodial diterpenoid from the leaves of Hyptis suaveolens, J. Ethnopharmacol. 102 (2005) 295-297.

[20] J.C. Barber, J. Francisco-Ortega, A. Santos-Guerra, K.G. Turner, R.K. Jansen, Origin of Macaronesian Sideritis L. (Lamioideae: Lamiaceae) inferred from nuclear and chloroplast sequence datasets, Mol. Phylogenet. Evol. 23 (2002) 293-306.

[21] H. Ohtsu, R. Tanaka, Y. In, S. Matsunaga, H. Tokuda, H. Nishino, New abietane diterpenoids from the cones of Larix kaempferi, Can. J. Chem. 78 (2000) 31-40.

[22] H. Ohtsu, R. Tanaka, Y. In, S. Matsunaga, H. Tokuda, H. Nishino, Abietane diterpenoids from the cones of Larix kaempferi and their inhibitory effects on EpsteinBarr virus activation, Planta Med. 67 (2001) 55-60. 